\title{
Dietary Administration of Banana (Musa acuminata) Peel Flour Affects the Growth, Antioxidant Status, Cytokine Responses, and Disease Susceptibility of Rohu, Labeo rohita
}

\author{
Sib Sankar Giri, ${ }^{1}$ Jin Woo Jun, ${ }^{1}$ Venkatachalam Sukumaran, ${ }^{2}$ and Se Chang Park ${ }^{1}$ \\ ${ }^{1}$ Laboratory of Aquatic Biomedicine, College of Veterinary Medicine and Research Institute for Veterinary Science, \\ Seoul National University, Seoul 151742, Republic of Korea \\ ${ }^{2}$ Department of Biotechnology, Periyar Maniammai University, Thanjavur, Tamil Nadu 613403, India \\ Correspondence should be addressed to Venkatachalam Sukumaran; drvsukumar@gmail.com and \\ Se Chang Park; parksec@snu.ac.kr
}

Received 24 November 2015; Revised 4 April 2016; Accepted 14 April 2016

Academic Editor: Ghislain Opdenakker

Copyright (C) 2016 Sib Sankar Giri et al. This is an open access article distributed under the Creative Commons Attribution License, which permits unrestricted use, distribution, and reproduction in any medium, provided the original work is properly cited.

To explore the feasibility of Musa acuminata (banana) peels as a feed additive, effects of banana peel flour (BPF) on the growth and immune functions of Labeo rohita were evaluated. Diets containing five different concentrations of BPF ( $0 \%$ [basal diet], 1\% [B1], $3 \%$ [B3], 5\% [B5], and 7\% [B7]) were fed to the fish (average weight: $15.3 \mathrm{~g}$ ) for 60 days. The final weight gain and specific growth rate were higher $(P<0.05)$ in the B5 group. The most significant improvements in immune parameters such as lysozyme, alternative complement pathway, leukocyte phagocytic, superoxide dismutase, and catalase activities were observed in the B5 group. However, the B5 group exhibited the lowest malondialdehyde activity. IgM and glutathione peroxidise activities were significantly elevated in the treatment groups, except in B1, after only 30 days of feeding. Of the examined cytokine-related genes, IL- $1 \beta$, TNF- $\alpha$, and HSP70 were upregulated in the head kidney and hepatopancreas, and expressions were generally higher in the B3 and B5 groups. Moreover, B5 group challenged with Aeromonas hydrophila 60 days after feeding exhibited the highest survival rate $(70 \% ; P<0.05)$. These results suggest that dietary BPF at $5 \%$ could promote growth performance and strengthen immunity in L. rohita.

\section{Introduction}

Global aquaculture production is dominated by freshwater fish species (56.4\%), especially carp species $(71.9 \% ; 24.2$ million tons in 2010) [1]. Intensive rearing of aquaculture fish species generates environmental stress to fish, which can increase susceptibility to various pathogens such as viruses, bacteria, fungi, and parasites [2]; this has led to a huge economic loss. The most common and frequently encountered bacterial pathogen in freshwater aquaculture is Aeromonas hydrophila, which causes severe damage to carps [3]. Treatment of infections by using antibiotics and chemotherapeutics at the farm level is either prohibited or infeasible because it may result in an increase in drug-resistant pathogens, environmental hazards, and food safety concerns [4]. Therefore, disease management approaches in aquaculture should be based on preventive measures rather than disease control or treatment, as they are likely to be more cost-effective. Currently, use of "immunostimulants" is gaining interest because of their potential in overcoming the limitations of vaccines and probiotics [5].

Fish respond to infectious agents via both specific and nonspecific mechanisms, but they rely primarily on nonspecific immune responses [6]. Therefore, boosting fish innate immunity may be the most promising approach for disease prevention. Plant extracts are known to promote growth; stimulate appetite; enhance tonicity and immunostimulation; facilitate maturation of cultured species; and possess stress reduction, sexual stimulation, and antipathogenic properties in fish [7]. Products of several herbal plants, for example, Azadirachta indica [5], Psidium guajava [8], Rheum officinale [9], Withania somnifera [10], Rehmannia glutinosa [2], Ficus 
carica polysaccharide [11], emodin [12, 13], and Achyranthes aspera [14], have been reported to enhance fish immunity. Moreover, some products of herbal plants have been reported to alter the expression of cytokine- and immune-related genes in fish $[2,8,11,14]$. They play vital role in host innate immunity and are indispensable for the use and activation of macrophages, neutrophils, and lymphocytes at infection sites for pathogen elimination [15].

Banana (Musa spp.) is vital for food security in many tropical and subtropical countries, and they are the most popular fruit in industrialized countries [16]. Banana is the second leading fruit produced after citrus, contributing to approximately $17 \%$ of the world's total fruit production; it is cultivated in over 130 countries [17]. Banana peel, which constitutes up to $35 \%$ of the ripe fruit, is a household and industrial food waste discarded in large quantities [18]. It is rich in dietary fibre, proteins, essential amino acids, vitamins, polyunsaturated fatty acids, and potassium [19]. Soluble fibres are well known to lower serum cholesterol and help reduce the risk of colon cancer [20]. Bioactive compounds like flavonoids, tannins, phlobatannins, alkaloids, glycosides, anthocyanins, and terpenoids were found in banana peels, and these compounds have been reported to exert various biological and pharmacological effects (antibacterial, antihypertensive, antidiabetic, and anti-inflammatory activities) [21]. Further, antioxidant compounds (e.g., prodelphinidins, polyphenols, catecholamines, and carotenoids) [22] and high amount of micronutrients [23] were found in the peels of genus Musa. The presence of various bioactive compounds in banana peels suggests that the peels possess various medicinal properties and may be useful as immunostimulant [24].

The effect of oral immunostimulants on the immune response in aquatic animals is strongly associated with the dose and duration of application. In the present study, we aimed to investigate the effects of dietary supplementation of banana peels on the growth, antioxidant status, immune parameters, and cytokine gene expression of $L$. rohita and its susceptibility to A. hydrophila infection. We also explored the potential of banana peel as a feed additive in aquaculture.

\section{Materials and Methods}

2.1. Diet Preparation. Bananas (Musa acuminata) were purchased from the local market (Thanjavur, Tamil Nadu) with a skin colour index of 6 (all yellow) [27]. The bananas were rinsed thoroughly in tap water, followed by double distilled water and acetone, to remove any contaminants. They were then separated into pulps and peels. The peels were cut into pieces of about $5 \mathrm{~cm}^{2}$ by using a kitchen knife and air dried in the oven at $50^{\circ} \mathrm{C}$ for $24 \mathrm{~h}$. Then, the pieces were ground into a fine powder by using the laboratory grinder. The obtained flour, called BPF, was stored at $-20^{\circ} \mathrm{C}$ until use.

The basal diet (Table 1) was prepared using a previously described method [8]. Proximate analysis of the basal diet [28] revealed a composition of $33.1 \%$ proteins, $8.9 \%$ lipids, and $12 \%$ ash. The basal diet was used as the control diet. The basal diet was supplemented with BPF at five concentrations: 0\% (control diet), 1\% (B1), 3\% (B3), 5\% (B5), and 7\% (B7). All ingredients were blended thoroughly into a mixture and then
TABLE 1: Formulation and chemical composition of basal diet $\left(\mathrm{g} \mathrm{kg}^{-1}\right.$ dry matter).

\begin{tabular}{lc}
\hline Ingredients & Concentrations $\left(\mathrm{g} \mathrm{kg}^{-1}\right)$ \\
\hline Ground nut oil cake & 390 \\
Rice bran & 340 \\
Soybean meal & 170 \\
Fish meal & 78 \\
Vegitable oil & 20 \\
Mineral and vitamin mixture & $\mathrm{a}$ \\
Proximate analysis $\left(\mathrm{g} \mathrm{kg}^{-1}\right)$ & 2 \\
$\quad$ Crude protein & 331 \\
$\quad$ Crude lipid & 89 \\
$\quad$ Ash & 120 \\
\hline
\end{tabular}

${ }^{a}$ Every $250 \mathrm{~g}$ of mineral-vitamin mixture (Supplevite-M, Sarabhai Zydus Animal Health Ltd., India) provides vitamin A, 500000 IU; vitamin D3, $100000 \mathrm{IU}$; vitamin B2, $0.2 \mathrm{~g}$; vitamin E, 75 units; vitamin $\mathrm{K}, 0.1 \mathrm{~g}$; calcium pantothenate, $0.25 \mathrm{~g}$; nicotinamide, $0.1 \mathrm{~g}$; vitamin B12, $0.6 \mathrm{mg}$; choline chloride, $15 \mathrm{~g}$; calcium, $75 \mathrm{~g}$; manganese, $2.75 \mathrm{~g}$; iodine, $0.1 \mathrm{~g}$; iron, $0.75 \mathrm{~g}$; zinc, $1.5 \mathrm{~g}$; copper, $0.2 \mathrm{~g}$; and cobalt, $0.045 \mathrm{~g}$.

pelletized, air-dried, ground, and sieved into an appropriate pellet size. The pellets were then stored at $-20^{\circ} \mathrm{C}$ until further use.

2.2. Experimental Design. Labeo rohita fingerlings (mean bodyweight: $15.3 \mathrm{~g}$ ) obtained from local fish farm (Thanjavur, Tamil Nadu, India) were acclimatised to laboratory conditions in $500 \mathrm{~L}$ plastic tanks at $26 \pm 2^{\circ} \mathrm{C}$ for 2 weeks and fed the basal diet. Approximately $20 \%$ of the water in all tanks was exchanged daily, and $100 \%$ of the water was exchanged every week. Basic physiochemical parameters of the water were measured every week [29]. Oxygen and ammonia concentrations were $6.1-7.3 \mu \mathrm{g} \mathrm{mL}^{-1}$ and $0.03-0.06 \mu \mathrm{g} \mathrm{mL}^{-1}$, respectively, and $\mathrm{pH}$ ranged from 7 to 8 throughout the study period.

The fish were randomly divided into five experimental groups, with three replicates in each group. Tank capacity was $200 \mathrm{~L}$, and each tank contained 25 fish (i.e., per group: $25 \times 3=75$ fish). The fish were fed one of the five diets for 60 days, and three times (at 08:00, 13:00, and 18:00 hours) at $3-5 \%$ of body weight daily. The amount of feed consumed was determined by daily recovery of excess feed, which was then adjusted every 15 days by batch weighing after $24 \mathrm{~h}$ of starvation.

2.3. Growth Performance. Ten fish were randomly selected from each tank (i.e., $10 \times 3=30$ fish per group) at day 0 , day 30 , and day 60 after experimental feeding and batch-weighed to estimate growth performance. Growth performance and survival rate of the fish were calculated using the following formulae: weight gain (WG; g/fish) $=W_{t}-W_{0}$; specific growth rate $(\mathrm{SGR})=100 \times\left[\left(\ln W_{t}-\ln W_{0}\right) / t\right]$; feed conversion ratio $(\mathrm{FCR})=\mathrm{FI} /\left(W_{t}-W_{0}\right)$, where $W_{t}$ and $W_{0}$ were final and initial weights of the fish, respectively; $t$ is the duration of feeding (in days); and FI is feed intake. 
2.4. Sample Collection. At the end of 30 days and 60 days of experimental feeding, five fish from each tank (i.e., 5 $\times 3=15$ fish per group) were collected to study immune and antioxidant parameters. Blood samples were collected by caudal venipuncture with a $1 \mathrm{~mL}$ syringe after anesthetizing the fish with diluted MS222 (Sigma-Aldrich, USA). The blood samples were transferred into Eppendorf tubes. After collection, blood was centrifuged at $2000 \times \mathrm{g}$ for $10 \mathrm{~min}$ at $4^{\circ} \mathrm{C}$. The obtained blood leucocytes and plasma were stored at $-20^{\circ} \mathrm{C}$ for further analysis.

\subsubsection{Immune Parameters}

(1) Serum Lysozyme Activity. Lysozyme activity was measured according to the method described by Ellis [30]. Briefly, the lysozyme substrate was $0.2 \mathrm{mg} \mathrm{mL}^{-1}$ of freeze-dried Micrococcus lysodeikticus (Sigma, USA) suspension in $0.05 \mathrm{M}$ Phosphate Buffer Solution (PBS), pH 6.2. Serum $(100 \mu \mathrm{L})$ was added to $1.9 \mathrm{~mL}$ of the bacterial suspension and the reduction in absorbance at $530 \mathrm{~nm}$ was measured after $0.5 \mathrm{~min}$ and $4.5 \mathrm{~min}$ at room temperature. Results were expressed in units of lysozyme activity $\mathrm{mL}^{-1}$ serum. One unit of lysozyme activity was defined as the amount of enzyme that produces a decrease in absorbance of $0.001 \mathrm{~min}^{-1} \mathrm{~mL}^{-1}$ serum.

(2) Alternative Complement Pathway (ACP) Activity Assay. ACP activity was determined and calculated using the method of Yano [31] by using rabbit red blood cells (RaRBC). Briefly, the RaRBC were adjusted to $2 \times 10^{8}$ cells $\mathrm{mL}^{-1}$ in $0.01 \mathrm{M}$ ethylene glycol tetraacetic acid-magnesium-gelatin veronal buffer (EGTA-Mg-GVB). The $100 \%$ lysis value was obtained by lysing of $100 \mathrm{~mL}$ of RaRBC with $3.4 \mathrm{~mL}$ of distilled water and measuring the optical density of haemolysate at $414 \mathrm{~nm}$ against distilled water. The test serum was diluted and different volumes ranging from 0.1 to $0.25 \mathrm{~mL}$ were made up to $0.25 \mathrm{~mL}$ total volume before being allowed to react with $0.1 \mathrm{~mL}$ of RaRBC in test tubes. After incubation at $20^{\circ} \mathrm{C}$ for 90 min with occasional shaking, $3.15 \mathrm{~mL}$ of a saline solution was added to each tube and centrifuged at $1600 \times \mathrm{g}$ for $10 \mathrm{~min}$ at $4^{\circ} \mathrm{C}$. The optical density of the supernatant was measured at $414 \mathrm{~nm}$ using a spectrophotometer (Beckman Instruments Inc., California, USA). The volume of serum that produces $50 \%$ haemolysis $\left(\mathrm{ACH}_{50}\right)$ was determined and the number of $\mathrm{ACH}_{50} \mathrm{U} \mathrm{mL}^{-1}$ was calculated for each group.

(3) Leucocyte-Phagocytic Assay. Staphylococcus aureus was cultured in an agar culture medium for $24 \mathrm{~h}$ at $37^{\circ} \mathrm{C}$. The

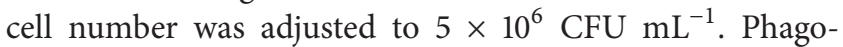
cytic activity (PA) of the blood leukocytes was determined according to the method described by Cai et al. [32]. Briefly, blood sample was collected into heparinized centrifuge tube and shaken well. Same volume of bacterial suspension was added to the tube. The tubes were then kept at $28^{\circ} \mathrm{C}$ in a water bath for $30 \mathrm{~min}$ and shaken every $10 \mathrm{~min}$. Following incubation, solution was centrifuged at $1500 \times \mathrm{g}$ for $5 \mathrm{~min}$ and the precipitate was used further. The upper layer of the precipitate was used to make blood slides. Slides were air dried, fixed with methanol for $3 \mathrm{~min}$, and then stained with Swiss staining solution for $5 \mathrm{~min}$. The number of phagocytotic and unphagocytotic leukocytes was counted under the microscope. PA was expressed as phagocytic rate (PR):

$$
\begin{aligned}
\operatorname{PR}(\%)=[100 \\
\left.\quad \times(\text { phagocytic leucocytes })(\text { total leucocytes })^{-1}\right] .
\end{aligned}
$$

(4) Immunoglobulin M (IgM) Assay. Plasma total IgM levels were measured according to the method described by Sharma et al. [10]. Briefly, blood sample was centrifuged for $5 \mathrm{~min}$ at $1000 \times \mathrm{g}$ to get clear cells. $0.1 \mathrm{~mL}$ of plasma was placed into a serum vial and added $0.1 \mathrm{~mL}$ of $12 \%$ polyethylene glycol (PEG) that had been suspended in deionised water and incubated at room temperature for $2 \mathrm{~h}$ under constant mixing. Following centrifugation at $5000 \times \mathrm{g}$ for $10 \mathrm{~min}$, supernatant was collected and protein concentration was determined. Protein reading from supernatant was the amount of protein taken out by absorption to PEG. Total immunoglobulin was expressed as unit $\mathrm{mg} \mathrm{mL}^{-1}$. Total immunoglobulin $=$ total protein in individual sample plasma - total protein taken out by absorption to polyethylene glycol.

\subsubsection{Antioxidant Parameters}

(1) Superoxide Dismutase (SOD) and Malondialdehyde (MDA) Assay. SOD activity was determined using an enzymatic assay method with a reagent kit (Randox, Crumlin, UK), as described by Zhang et al. [33]. MDA content was measured using barbituric acid reaction chronometry [34].

(2) Measurement of Catalase (CAT) Activity and Glutathione Peroxidise (GPX) Activity. CAT activity was measured by the rate of decrease in $\mathrm{H}_{2} \mathrm{O}_{2}$ absorbance at $240 \mathrm{~nm}$ by using a commercially available kit (Sigma-Aldrich, USA). GPx activity was measured using a commercial kit (Ransel RS-504, Randox), according to the manufacturer's instructions. Specific activity was expressed as GPx unit $\mathrm{mg}^{-1}$ of total protein.

\subsection{Expressions of Immune-Related Genes in the Head Kidney} and Hepatopancreas. The head kidney and hepatopancreases were dissected from nine fish per group at the end of the feeding trial. Total RNA was extracted from the tissues (kidney and hepatopancreas) by using TRIZOL reagent (Invitrogen, USA), according to the manufacturer's instructions. RNA concentration and purity were analysed using a spectrophotometer (Thermo Scientific, USA), and quality was checked using $1 \%$ agarose gel containing $0.5 \mu \mathrm{g} \mathrm{mL} L^{-1}$ ethidium bromide. RNA was reverse-transcribed to cDNA by using the SuperScript ${ }^{\circledR}$ cDNA synthesis kit (Life Technologies), according to the manufacturer's instructions. Real-time PCR analysis of $I L-1 \beta, I L-10, i N O S, T N F-\alpha, T G F-\beta, H S P 70$, $N F-\kappa B$, and a housekeeping gene ( $\beta$-actin) was performed using CFX96 ${ }^{\mathrm{TM}}$ Real-Time PCR (Bio-Rad, Laboratories, Inc.), according to standard protocols with primer sequences and thermocycling conditions as indicated in Table 2 . To verify the accuracy of each amplicon, melt curve analysis was performed after amplification. All samples were run in parallel with the housekeeping gene to normalize cDNA loading. Gene expression results were analysed using the $2^{-\Delta \Delta \mathcal{C}_{\mathrm{T}}}$ 
TABLE 2: Real-time primer sequences and thermocycling conditions.

\begin{tabular}{|c|c|c|c|}
\hline Target gene & Primer sequence $\left(5^{\prime}\right.$ to $\left.3^{\prime}\right)$ & Thermocycling conditions & Reference/accession number \\
\hline \multirow{2}{*}{ IL- $1 \beta$} & ACСССАCAAAACATCGGCCAACC & $95^{\circ} \mathrm{C} 30 \mathrm{~s}, 40$ cycles of $95^{\circ} \mathrm{C} 5 \mathrm{~s}, 61.5^{\circ} \mathrm{C} 30 \mathrm{~s}$, & \multirow{2}{*}[25]{} \\
\hline & ТСТТСТССАТТТССАСССТСТС & and $72^{\circ} \mathrm{C} 30 \mathrm{~s}$ & \\
\hline \multirow{2}{*}{ IL-10 } & CGCAGTGCAGAAGAGTCGAC & $95^{\circ} \mathrm{C} 30 \mathrm{~s}, 40$ cycles of $95^{\circ} \mathrm{C} 5 \mathrm{~s}, 61.5^{\circ} \mathrm{C} 30 \mathrm{~s}$, & \multirow{2}{*}{ GU256643 } \\
\hline & CCCGCTTGAGATCCTGAAATAT & and $72^{\circ} \mathrm{C} 30 \mathrm{~s}$ & \\
\hline \multirow{2}{*}{ TNF- $\alpha$} & CTCAACAAGTCTCAGAACAATCAGG & $95^{\circ} \mathrm{C} 30 \mathrm{~s}, 40$ cycles of $95^{\circ} \mathrm{C} 5 \mathrm{~s}, 61.5^{\circ} \mathrm{C} 30 \mathrm{~s}$ & \multirow{2}{*}[25]{} \\
\hline & TCCTGGTTCCTTCTCCAATCTAGCT & and $72^{\circ} \mathrm{C} 30 \mathrm{~s}$ & \\
\hline \multirow{2}{*}{ iNOS } & GGAGGTACGTCTGCGAGGAGGCT & $95^{\circ} \mathrm{C} 30 \mathrm{~s}, 40$ cycles of $95^{\circ} \mathrm{C} 5 \mathrm{~s}, 61.1^{\circ} \mathrm{C} 30 \mathrm{~s}$ & \multirow{2}{*}[8]{} \\
\hline & CCAGCGCTGCAAACCTATCATCCA & and $72^{\circ} \mathrm{C} 30 \mathrm{~s}$ & \\
\hline \multirow{2}{*}{ TGF- $\beta$} & ACGCTTTATTCCCAACCAAA & $95^{\circ} \mathrm{C} 30 \mathrm{~s}, 40$ cycles of $95^{\circ} \mathrm{C} 5 \mathrm{~s}, 61.5^{\circ} \mathrm{C} 30 \mathrm{~s}$ & \multirow[b]{2}{*}{ AF13694 } \\
\hline & GAAATCCTTGCTCTGCCTCA & and $72^{\circ} \mathrm{C} 30 \mathrm{~s}$ & \\
\hline \multirow{2}{*}{$\mathrm{NF}-\kappa \mathrm{B}$} & TATTCAGTGCGTGAAGAAG & $95^{\circ} \mathrm{C} 30 \mathrm{~s}, 40$ cycles of $95^{\circ} \mathrm{C} 5 \mathrm{~s}, 61.5^{\circ} \mathrm{C} 30 \mathrm{~s}$, & \multirow{2}{*}{ LN590704 } \\
\hline & TATTAAAGGGGTTGTTCTGT & and $72^{\circ} \mathrm{C} 30 \mathrm{~s}$ & \\
\hline \multirow{2}{*}{ HSP70 } & GGCAGAAAGTTTGATGACCCA & $95^{\circ} \mathrm{C} 30 \mathrm{~s}, 40$ cycles of $95^{\circ} \mathrm{C} 5 \mathrm{~s}, 61.5^{\circ} \mathrm{C} 30 \mathrm{~s}$, & \multirow{2}{*}[26]{} \\
\hline & GCAATCTCСТTCATATTCACC & C 30 & \\
\hline \multirow{2}{*}{$\beta$-actin } & AGACCACCTTCAACTCCATCATG & $95^{\circ} \mathrm{C} 30 \mathrm{~s}, 40$ cycles of $95^{\circ} \mathrm{C} 5 \mathrm{~s}, 61.5^{\circ} \mathrm{C} 30 \mathrm{~s}$ & \multirow{2}{*}[25]{} \\
\hline & TCCGATCCAGACAGAGTATTTACGC & and $72^{\circ} \mathrm{C} 30 \mathrm{~s}$ & \\
\hline
\end{tabular}

method after verifying that the primers were amplified with an efficiency of approximately $100 \%$ [26], where $\Delta \Delta \mathrm{C}_{\mathrm{T}}=\left[\left(\mathrm{C}_{\mathrm{T}}\right.\right.$ gene of interest $-\mathrm{C}_{\mathrm{T}} \beta$-actin $)$ treatment group $-\left(\mathrm{C}_{\mathrm{T}}\right.$ gene of interest $-\mathrm{C}_{\mathrm{T}} \beta$-actin) control group]. The $\mathrm{C}_{\mathrm{T}}$ is defined as the PCR cycle at which the fluorescent signal of the reporter dye crosses an arbitrarily placed threshold.

2.6. Challenge Test. Seven-day lethal dose $50\left(\mathrm{LD}_{50}\right)$ for A. hydrophila MTCC-1739 was $10^{7} \mathrm{CFU} / \mathrm{mL}$, as determined earlier in our laboratory [8], and this strain was reisolated from experimentally infected fish in our laboratory. At the termination of the feeding trial, 10 fish from each tank (i.e., 3 $\times 10=30$ fish per group) were selected for the challenge test. The fish $(n=30)$ were injected intraperitoneally with $100 \mu \mathrm{L}$ of phosphate-buffered saline (PBS) containing $1 \times 10^{7}$ live $A$. hydrophila. For negative control, 10 fish were injected with PBS only. The challenged fish were kept under observation for 14 days and fed the basal diet. Mortality of the fish in each tank was observed over 14 days.

2.7. Statistical Analysis. One-way analysis of variance (ANOVA) was used to analyse the data. Multiple comparisons were performed using Tukey's test to analyse the differences between treatments. All statistical analyses were performed using the OriginPro software (version 8; OriginLab Corporation, Northampton, USA). The level of significance was set at $P<0.05$, and the results were expressed as mean \pm SEM.

\section{Results}

3.1. Growth Performance. Effects of BPF on the growth performance of L. rohita are shown in Table 3. After 30 days of feeding, significantly higher WG and SGR were observed in the B5 group than in the control. However, 30 days of $\mathrm{BPF}$ administration had no significant effects on FCR. At the end of the trial, WG and SGR were higher in the treatment groups, and the highest $(P<0.05) \mathrm{WG}(83.61 \pm 1.52 \mathrm{~g})$ and SGR $(2.86 \pm 0.023 \mathrm{~g})$ values were observed in the B5 group (compared to the control). FCR was significantly lower in the B5 group $(4.39 \pm 0.02)$ than in the control.

3.2. Immune Parameters. Results of LA and ACP activities are shown in Table 4. Serum lysozyme activity was significantly higher in the $\mathrm{B} 5$ group during the whole period of the trial than in the control. ACP activity was significantly higher in the treatment groups, except B1, at any point of time, and it was the highest in the B5 group (Table 4). A slight decline in LA and ACP activities was observed at a higher $\mathrm{BPF}$ concentration (i.e., B7) during the trial period.

Effects of dietary administration of BPF on PA and IgM of L. rohita are shown in Table 5. After 30 days of feeding, significantly higher PA was observed in the treatment groups, except B1, than in the control. However, PA was significantly higher in the treatment groups at the end of the feeding trial, and the highest activity was recorded in the B5 group (48.70土 $1.68 \%)$. IgM level was significantly higher in the treatment groups, except B1, during the 30 days of feeding. However, 60 days of feeding with BPF did not have a significant effect on IgM levels, although a slight increase in IgM level (compared to the control) was recorded in the B1 group. Surprisingly, IgM levels were lower in the other treatment groups than in the control, and the lowest level $(P<0.05)$ was observed in the $\mathrm{B} 7$ group.

3.3. Antioxidant Parameters. SOD activity was significantly higher in the $\mathrm{B} 5$ and $\mathrm{B} 7$ groups than in the control at any point 
TABLE 3: Effects of banana peel flour (BPF) on the growth performance of Labeo rohita.

\begin{tabular}{lccccc}
\hline Parameters & Control & B1 & B3 & B5 & B7 \\
\hline Initial weight (g) & $15.37 \pm 0.41$ & $15.62 \pm 0.24$ & $15.18 \pm 0.68$ & $15.21 \pm 0.27$ & $15.6 \pm 0.46$ \\
\hline 0-30 days of feeding & & & & & \\
WG (g) & $38.06 \pm 0.44^{\mathrm{a}}$ & $38.65 \pm 0.28^{\mathrm{ab}}$ & $39.24 \pm 0.57^{\mathrm{ab}}$ & $40.97 \pm 0.39^{\mathrm{b}}$ & $39.63 \pm 0.48^{\mathrm{ab}}$ \\
SGR & $2.94 \pm 0.017^{\mathrm{a}}$ & $2.95 \pm 0.041^{\mathrm{a}}$ & $3.08 \pm 0.032^{\mathrm{b}}$ & $3.14 \pm 0.024^{\mathrm{cb}}$ & $3.03 \pm 0.015^{\mathrm{ab}}$ \\
FCR & $5.84 \pm 0.21$ & $5.83 \pm 0.18$ & $5.81 \pm 0.29$ & $5.78 \pm 0.36$ & $5.81 \pm 0.24$ \\
Survival (\%) & 100 & 100 & 100 & & 100 \\
\hline 0-60 days of feeding & & & & $83.61 \pm 1.52^{\mathrm{b}}$ & $80.07 \pm 1.18^{\mathrm{b}}$ \\
Final weight gain (g) & $74.19 \pm 1.66^{\mathrm{a}}$ & $77.06 \pm 1.09^{\mathrm{ab}}$ & $81.42 \pm 1.22^{\mathrm{b}}$ & $2.86 \pm 0.023^{\mathrm{b}}$ & $2.72 \pm 0.029^{\mathrm{ba}}$ \\
SGR & $2.63 \pm 0.047^{\mathrm{a}}$ & $2.66 \pm 0.053^{\mathrm{ab}}$ & $2.78 \pm 0.031^{\mathrm{b}}$ & $4.36 \pm 0.02^{\mathrm{b}}$ & $4.52 \pm 0.03^{\mathrm{ba}}$ \\
FCR & $4.61 \pm 0.03^{\mathrm{a}}$ & $4.54 \pm 0.01^{\mathrm{a}}$ & $4.48 \pm 0.05^{\mathrm{ba}}$ & 100 & 97.33 \\
Survival (\%) & 100 & 98.66 & 100 & & 100 \\
\hline
\end{tabular}

Note: $\mathrm{WG}=$ weight gain; $\mathrm{SGR}$ = specific growth rate; FCR = feed conversion ratio.

Values in the same column with different superscript letters are significantly different $(P<0.05)$. Values are presented as mean \pm SEM $(n=30$ fish in each group).

TABLE 4: Lysozyme (LA) and alternative complement pathway (ACP) activities observed on different sampling days after feeding Labeo rohita with banana peel flour (BPF) supplemented diets.

\begin{tabular}{|c|c|c|c|c|}
\hline \multirow{3}{*}{ Diet } & \multicolumn{4}{|c|}{ Immune response } \\
\hline & \multicolumn{2}{|c|}{$\mathrm{LA}\left(\right.$ unit $\mathrm{mL}^{-1}$ ) } & \multicolumn{2}{|c|}{$\mathrm{ACP}\left(\mathrm{ACH}_{50}{ }^{\mathrm{b}}\right.$ unit $\left.\mathrm{mL}^{-1}\right)$} \\
\hline & 30 days & 60 days & 30 days & 60 days \\
\hline Control & $69.3 \pm 1.73^{\mathrm{a}}$ & $71.2 \pm 1.64^{\mathrm{a}}$ & $103.1 \pm 2.18^{\mathrm{a}}$ & $111.4 \pm 1.78^{\mathrm{a}}$ \\
\hline B1 & $71.5 \pm 2.3^{\mathrm{ab}}$ & $74.6 \pm 1.91^{\mathrm{a}}$ & $107.9 \pm 2.73^{\mathrm{a}}$ & $119.1 \pm 2.81^{\mathrm{a}}$ \\
\hline B3 & $76.1 \pm 2.64^{\mathrm{ab}}$ & $82.1 \pm 1.1^{\mathrm{b}}$ & $118.4 \pm 3.11^{\mathrm{b}}$ & $131.7 \pm 3.06^{\mathrm{c}}$ \\
\hline B5 & $81.2 \pm 2.51^{\mathrm{b}}$ & $86.9 \pm 1.96^{\mathrm{b}}$ & $136.7 \pm 1.53^{\mathrm{c}}$ & $143.1 \pm 2.21^{\mathrm{c}}$ \\
\hline B7 & $79.3 \pm 1.52^{\mathrm{ba}}$ & $80.6 \pm 0.87^{\mathrm{ba}}$ & $127.6 \pm 2.01^{\mathrm{cb}}$ & $129.4 \pm 1.82^{\mathrm{cb}}$ \\
\hline
\end{tabular}

Values are expressed as mean $\pm \operatorname{SEM}(n=15)$. Mean values in the same column with different superscript letters vary significantly $(P<0.05)$.

TABle 5: Phagocytic activity (PA) and immunoglobulin (IgM) activities observed on different sampling days after feeding Labeo rohita with banana peel flour (BPF) supplemented diets.

\begin{tabular}{lcccc}
\hline \multirow{4}{*}{ Diet } & \multicolumn{4}{c}{ Immune response } \\
& 30 days & 60 days & 30 days & 60 days \\
\hline Control & $34.37 \pm 1.73^{\mathrm{a}}$ & $36.10 \pm 0.64^{\mathrm{a}}$ & $5.13 \pm 0.18^{\mathrm{a}}$ & $5.42 \pm 0.24^{\mathrm{a}}$ \\
B1 & $36.20 \pm 2.1^{\mathrm{ab}}$ & $39.76 \pm 1.27^{\mathrm{b}}$ & $5.40 \pm 0.16^{\mathrm{a}}$ & $5.91 \pm 0.19^{\mathrm{a}}$ \\
B3 & $37.66 \pm 2.64^{\mathrm{b}}$ & $44.06 \pm 2.39^{\mathrm{b}}$ & $7.16 \pm 0.26^{\mathrm{b}}$ & $5.36 \pm 0.31^{\mathrm{ab}}$ \\
B5 & $41.33 \pm 2.51^{\mathrm{c}}$ & $48.70 \pm 1.68^{\mathrm{c}}$ & $8.43 \pm 0.32^{\mathrm{c}}$ & $5.08 \pm 0.21^{\mathrm{ab}}$ \\
B7 & $42.20 \pm 1.52^{\mathrm{c}}$ & $45.16 \pm 1.37^{\mathrm{b}}$ & $7.33 \pm 0.14^{\mathrm{b}}$ & $4.34 \pm 0.17^{\mathrm{b}}$ \\
\hline
\end{tabular}

Values are expressed as mean $\pm \operatorname{SEM}(n=15)$. Mean values in the same column with different superscript letters vary significantly $(P<0.05)$.

of time (Table 6). The highest SOD activity was observed in the $\mathrm{B} 5$ group at any point of time.

After 30 days of feeding, significantly lower MDA activities were observed in the B3, B5, and B7 groups than in the control (Table 6). However, at end of the trial, significantly lower MDA activities were recorded in the $\mathrm{B} 5$ and $\mathrm{B} 7$ groups.
TABLE 6: Superoxide dismutase (SOD) and malondialdehyde (MDA) activities observed on different sampling days after feeding Labeo rohita with banana peel flour (BPF) supplemented diets.

\begin{tabular}{|c|c|c|c|c|}
\hline \multirow{3}{*}{ Diet } & \multicolumn{4}{|c|}{ Immune response } \\
\hline & \multicolumn{2}{|c|}{ SOD activity (unit $\mathrm{mL}^{-1}$ ) } & \multicolumn{2}{|c|}{$\operatorname{MDA}\left(\mathrm{nmol} \mathrm{mL} L^{-1}\right)$} \\
\hline & 30 days & 60 days & 30 days & 60 days \\
\hline Control & $43.1 \pm 1.04^{\mathrm{a}}$ & $44.5 \pm 0.78^{\mathrm{a}}$ & $9.16 \pm 0.29^{\mathrm{a}}$ & $8.24 \pm 0.26^{\mathrm{a}}$ \\
\hline B1 & $43.83 \pm 0.88^{\mathrm{a}}$ & $47.3 \pm 0.62^{\mathrm{ad}}$ & $8.83 \pm 0.43^{\mathrm{ab}}$ & $7.61 \pm 0.43^{\mathrm{ab}}$ \\
\hline B3 & $47.36 \pm 0.65^{\mathrm{ab}}$ & $49.93 \pm 0.91^{\mathrm{bd}}$ & $7.71 \pm 0.26^{\mathrm{bc}}$ & $7.12 \pm 0.32^{\mathrm{ab}}$ \\
\hline B5 & $49.28 \pm 0.95^{\mathrm{b}}$ & $52.5 \pm 0.78^{\mathrm{b}}$ & $7.23 \pm 0.31^{c}$ & $6.66 \pm 0.24^{\mathrm{b}}$ \\
\hline B7 & $49.2 \pm 1.19^{\mathrm{b}}$ & $48.7 \pm 0.53^{\mathrm{cd}}$ & $7.56 \pm 0.19^{\mathrm{cb}}$ & $7.32 \pm 0.44^{\mathrm{b}}$ \\
\hline
\end{tabular}

Values are expressed as mean \pm SEM $(n=15)$. Mean values in the same column with different superscript letters vary significantly $(P<0.05)$.

The lowest MDA activity was recorded in the B5 group after 60 days of feeding.

CAT activity was significantly higher in the B5 and B7 groups than in the control (Table 7), and the highest CAT activity was recorded in the $\mathrm{B} 5$ group.

GPx activities were significantly higher in the B5 and B7 groups than in the control after 30 days of feeding, and the highest GPx activity was recorded in the B7 group (Table 7).

3.4. Gene Expression Analysis. Expression profiles of immunerelated genes were examined in the head kidney and hepatopancreas of the fish $(n=9)$ at the end of the feeding trial. Transcription levels of TNF- $\alpha, I L-1 \beta$, and HSP70 were upregulated in the organs of fish fed the experimental diets (Figure 1), whereas expressions of $I L-10, i N O S, N F-\kappa B$, and TGF- $\beta$ were downregulated (Figure 2).

The B5 group exhibited the highest $(P<0.05)$ TNF- $\alpha$ mRNA expression in the head kidney and hepatopancreas tissues (Figure 1(a)). IL-1 $\beta$ mRNA expression was the highest $(P<0.05)$ in the head kidneys of the B5 group, followed by $\mathrm{B} 3$, whereas $I L-1 \beta$ expression was the lowest in the hepatopancreas (Figure 1(b)). HSP70 expression was significantly higher in the head kidneys of the B3 and B7 groups, and 
TABLE 7: Catalase (CAT) activity and glutathione peroxidase (GPx) level measured on different sampling days after feeding Labeo rohita with banana peel flour (BPF) supplemented diets.

\begin{tabular}{lcccc}
\hline Diet & \multicolumn{2}{c}{ Immune response } & \multicolumn{2}{c}{ GPx (unit per mg ${ }^{-1}$ of protein) } \\
& 30 days & 60 days & 30 days & 60 days \\
\hline Control & $13.43 \pm 0.64^{\mathrm{a}}$ & $14.07 \pm 0.48^{\mathrm{a}}$ & $15.46 \pm 0.87^{\mathrm{a}}$ & $15.87 \pm 0.23^{\mathrm{a}}$ \\
B1 & $14.17 \pm 0.81^{\mathrm{ab}}$ & $14.83 \pm 0.62^{\mathrm{ab}}$ & $16.83 \pm 0.57^{\mathrm{ab}}$ & $17.31 \pm 0.54^{\mathrm{a}}$ \\
B3 & $14.63 \pm 0.52^{\mathrm{ac}}$ & $16.52 \pm 0.46^{\mathrm{bc}}$ & $19.6 \pm 0.64^{\mathrm{bc}}$ & $17.06 \pm 0.81^{\mathrm{a}}$ \\
B5 & $16.41 \pm 0.67^{\mathrm{bc}}$ & $17.8 \pm 0.83^{\mathrm{c}}$ & $21.04 \pm 0.72^{\mathrm{c}}$ & $16.54 \pm 0.47^{\mathrm{a}}$ \\
B7 & $15.82 \pm 0.79^{\mathrm{c}}$ & $15.2 \pm 0.61^{\mathrm{ca}}$ & $21.36 \pm 0.92^{\mathrm{c}}$ & $15.72 \pm 0.91^{\mathrm{a}}$ \\
\hline
\end{tabular}

Values are expressed as mean \pm SEM $(n=15)$. Mean values in the same column with different superscript letters vary significantly $(P<0.05)$.

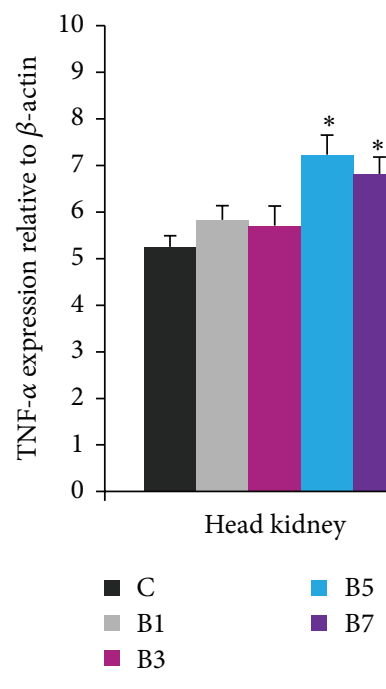

(a)

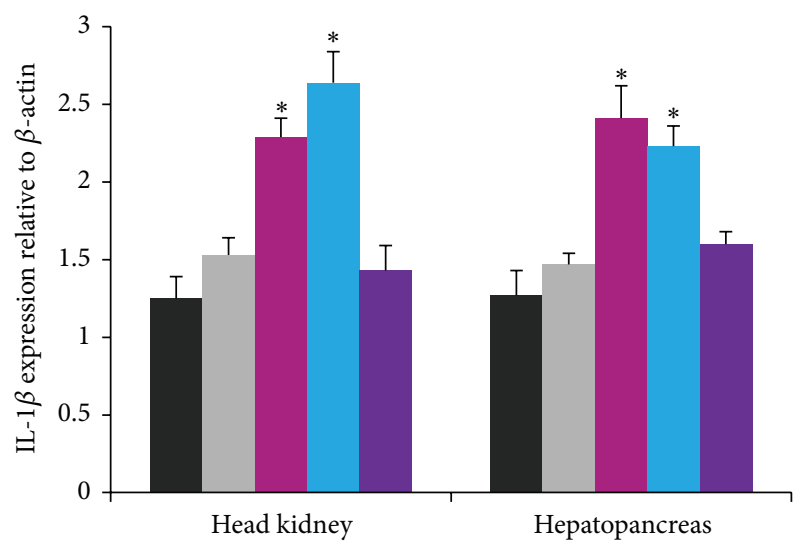

- $\mathrm{C} \quad \mathrm{B} 5$

- $\mathrm{B} 1$

(b)

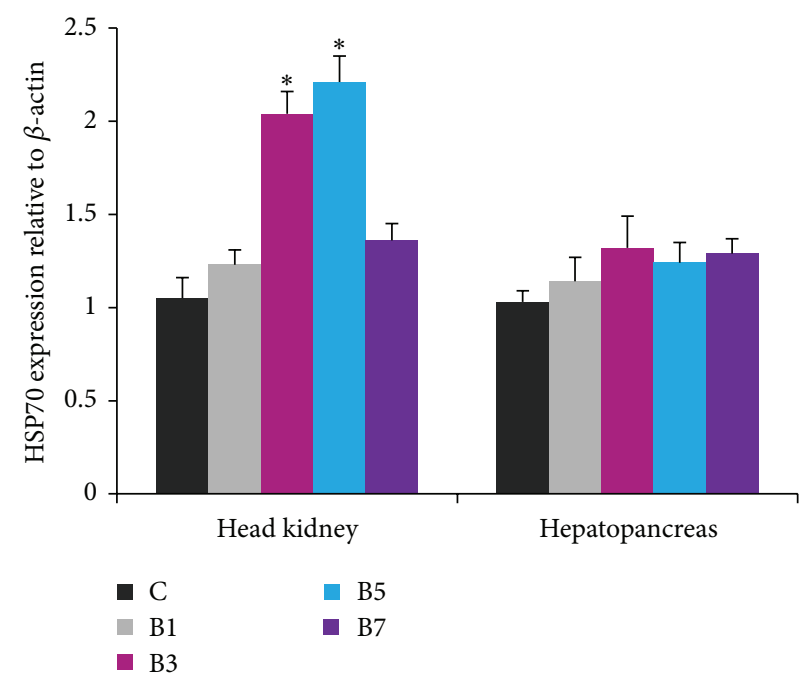

(c)

FIGURE 1: Relative mRNA expressions of upregulated genes (TNF- $\alpha, I L-1 \beta$, and HSP70) in the head kidney and hepatopancreas of Labeo rohita fed banana peel flour (BPF) supplemented diets. A significant difference is denoted by an asterisk $(P<0.05)$. Each bar represents mean \pm $\operatorname{SEM}(n=9)$. 


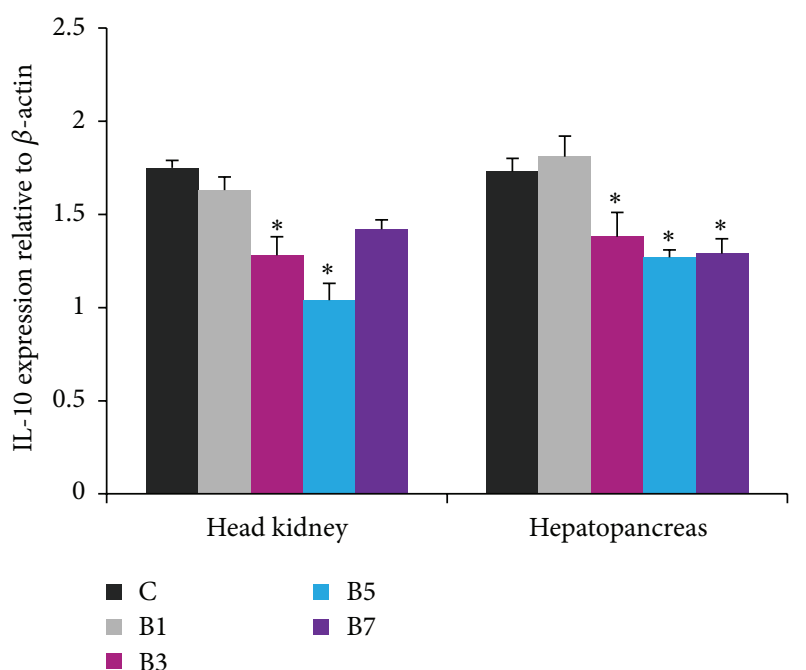

(a)

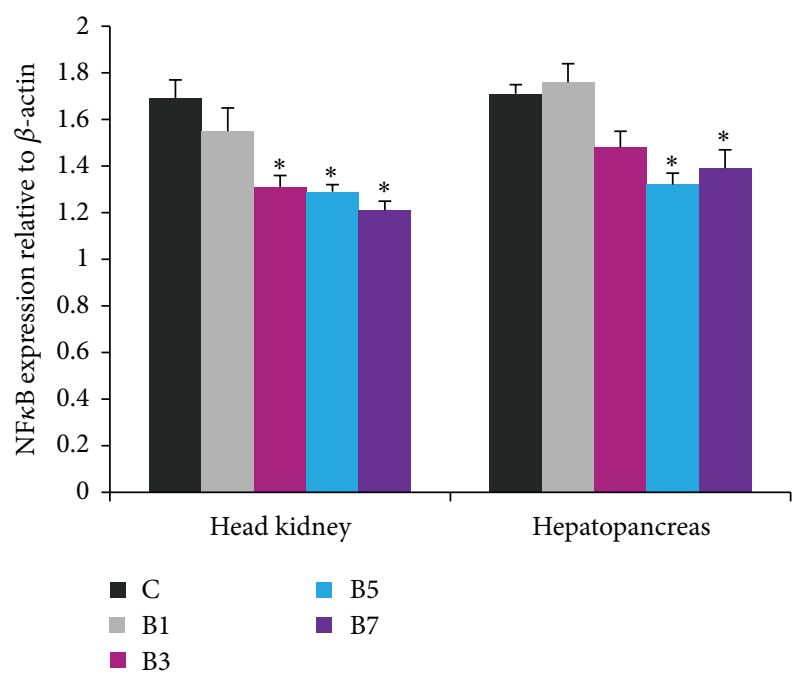

(c)

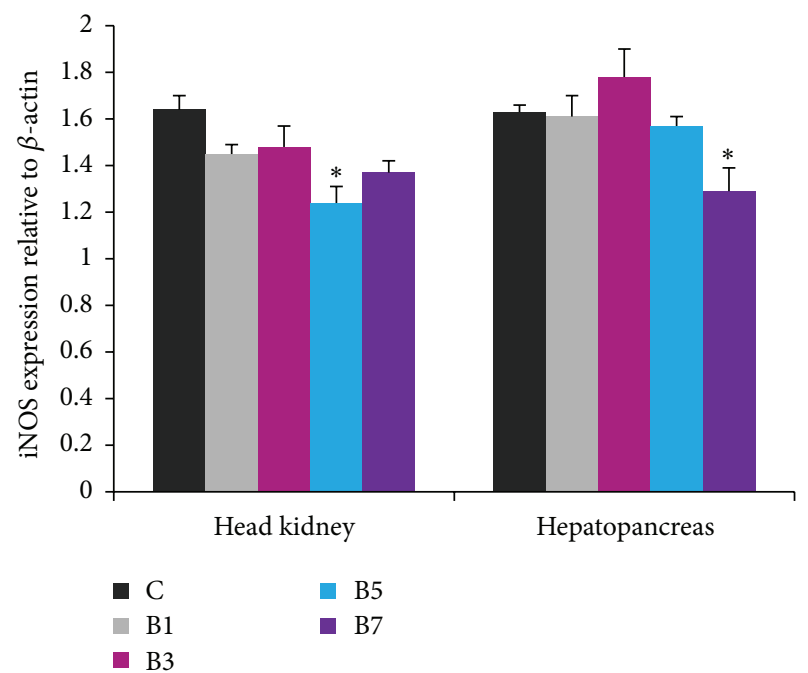

(b)

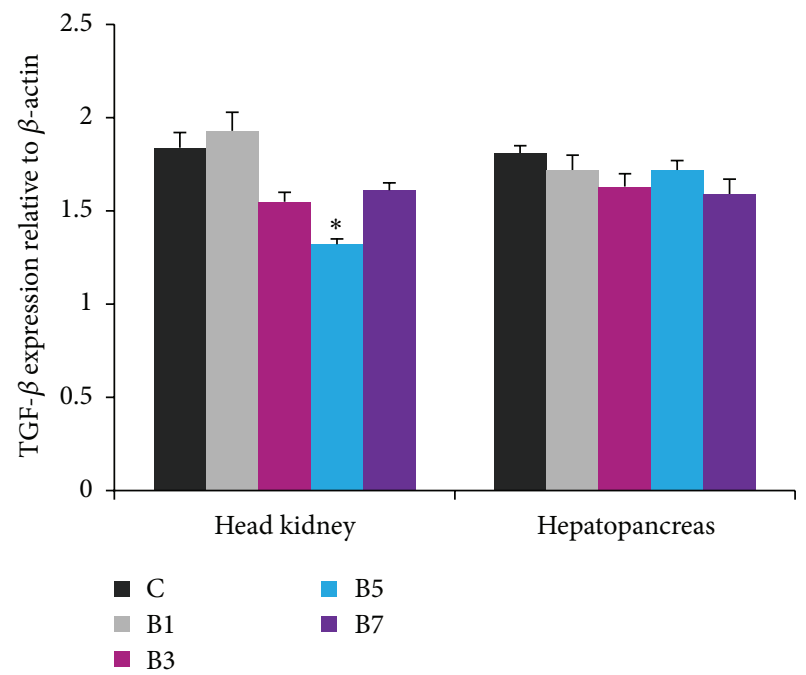

(d)

FiguRE 2: Relative mRNA expressions of $I L-10, i N O S, N F-\kappa B$, and TGF- $\beta$ in the head kidney and hepatopancreas of Labeo rohita fed banana peel flour (BPF) supplemented diets. A significant difference is denoted by an asterisk $(P<0.05)$. Each bar represents mean \pm SEM $(n=9)$.

the highest $H S P 70$ expression was observed in the B5 group (Figure 1(c)). However, dietary treatments had no significant effect on HSP70 expression in the hepatopancreas.

Effects of BPF on $I L-10, i N O S, N F-\kappa B$, and TGF $\beta$ expressions are shown in Figure 2. IL-10 expression was downregulated in the B3 and B5 groups, and the lowest level was observed in the B5 group (Figure 2(a)). Expression of $i N O S$ was downregulated $(P<0.05)$ in the B5 and B7 groups (Figure 2(b)). In addition, a slight increase in iNOS expression was observed in the hepatopancreas of the B3 group (Figure 2(b)). NF- $\kappa B$ expression was downregulated in both the B5 and B7 groups (Figure 2(c)). TGF- $\beta$ expression was significantly lower in only the head kidney of the B5 group (Figure 2(d)).

3.5. Challenge Test. Dietary supplementation of BPF for a longer period enhanced the resistance of $L$. rohita to
A. hydrophila infection. The highest postchallenge survival (70\%) was recorded in the $\mathrm{B} 5$ group, whereas the lowest postchallenge survival rate $(20 \%)$ was observed in the fish fed the basal diet. The B3 group exhibited a survival rate of $56.6 \%$, followed by the B7 (40\%) and B1 (26.66\%) groups. No mortality was observed in the group injected with PBS alone. Typical symptoms of haemorrhagic septicaemia were observed in moribund or dead fish. Colonies of A. hydrophila were isolated from dead fish.

\section{Discussion}

In the present study, dietary supplementation with $5 \% \mathrm{BPF}$ (i.e., B5) for 60 days significantly increased WG and SGR in L. rohita. Recently, we demonstrated that dietary administration of emodin (at $30 \mathrm{mg} \mathrm{kg}^{-1}$ of diet) [13] or guava leaves (at $0.5 \%$ ) [8] for 60 days significantly increased the growth 
performance of L. rohita. Nonprotein energy sources such as carbohydrates and lipids in the diets have the ability to spare dietary proteins by reducing the catabolism of proteins for energy, which can improve retention and ultimately growth in animals [35]. Further, significant reduction in FCR in the B5 group suggested that the fish utilised dietary nutrients more efficiently when feed was supplemented with BPF. However, owing to the complexity of the components used in herbal preparations, the direct cause of growth stimulation is unclear.

A complex system of numerous types of antioxidants (e.g., catalase, glutathione, SOD, and various peroxidases) is present in aquatic animals [9]. SOD, GPx, and CAT are important biochemical parameters and the first line of antioxidant enzymatic defence. Therefore, measurement of these antioxidant parameters may provide a hint of the antioxidant status in fish, and these parameters can serve as biomarkers for oxidative stress [33]. In the present study, supplementation of $5 \%$ BPF (i.e., B5) for 60 days resulted in the highest SOD and CAT activities, whereas MDA activity was lowered considerably $(P<0.05)$. In addition, supplementation of BPF significantly enhanced GPx for up to 30 days, and, thereafter, increment was not significant. Similar results were observed in L. rohita [13], Megalobrama terminalis [33], Ctenopharyngodon idella [36], and Megalobrama amblycephala [12] after dietary administration with herbal immunostimulants. Our results revealed that BPF at an appropriate concentration could stimulate the secretion of antioxidant enzymes as well as antioxidants, which can efficiently eliminate excess free radicals and regulate the balance of free radical in the body, resulting in improved antioxidant ability [33]. Further, lower MDA content observed in the present study also strengthened the higher antioxidant potential of BPF because MDA has strong biotoxicity and can damage cell structure and function [37]. Bioactive compounds such as phenolic compounds in banana peel may be responsible for the antioxidant activity [22]. Antioxidant potential of banana peels has also been reported in previous studies $[22,24]$.

As the first line of defence, various peptides such as lysozyme, antibodies, and complement factors inhibit the adhesion and colonization of microorganisms, leading to the prevention of infection and disease [35]. Phagocytosis has also been recognised as an important cellular process in the nonspecific immune system of fish [38]. In the present study, dietary supplementation with $3 \%$ (B3) or 5\% BPF (B5) for 60 days augmented $(P<0.05)$ serum LA, ACP, and PA in fish, with the highest degree of activity exhibited by the B5 group. Several recent studies have reported that dietary supplementation of plant products enhanced these immune parameters in carp $[2,5,8,10,13]$, which is consistent with our results. However, higher levels of BPF administration for a longer period had no significant effect on these immune parameters. This is most likely because higher doses of immunostimulants administered over longer periods often lead to immunosuppression, but the exact underlying reason is still unclear.

The predominant antibody type in fish, IgM, is used to identify and neutralize foreign objects such as bacteria and viruses [39]. In the present study, supplementation of $3 \%$ to $7 \%$ BPF improved $(P<0.05)$ IgM levels in fish up to 30 days, and thereafter the levels gradually decreased. Similar trend of IgM levels has also been reported in previous studies $[8,10,13]$. In line with earlier reports, it can be suggested that stimulation of IgM level is a temporary phenomenon attributable to immunostimulants.

Our study also provides evidence that dietary supplementation with BPF could efficiently regulate the expressions of certain cytokine-related genes in L. rohita. IL- $\beta$ and TNF$\alpha$ expression levels are generally considered to be indicators of inflammatory response [40], and they can regulate the production of other cytokines [2]. Coexpression of IL- $1 \beta$ and TNF- $\alpha$ is not unusual because they share similar roles in the initiation of immune response [41]. We found that dietary administration of 5\% BPF (B5) significantly upregulated the expressions of $I L-1 \beta$ and $T N F-\alpha$ in both examined tissues. Recently, we demonstrated that administration of $0.3 \%$ or $0.5 \%$ guava leaves for 60 days significantly augmented the expressions of $I L-1 \beta$ and $T N F-\alpha$ in the head kidney, intestine, and hepatopancreas of L. rohita [8]. Dietary administration of R. glutinosa augmented the expressions of $I L-1 \beta$ and TNF$\alpha$ genes in the common carp, Cyprinus carpio [2]. However, abundance of the two genes differed in the same organ of fish that were fed various levels of BPF.

iNOS and nitric oxide (NO) are recognised immunoregulatory factors in the defence against various pathogens in fish [8]. Recently, we observed that dietary administration of guava leaves significantly downregulated the expressions of $i N O S$ and $N F-\kappa B$ in L. rohita [8]. In the present study, we observed that dietary administration of BPF downregulated the expressions of $N F-\kappa B$ in the examined tissues, whereas $i N O S$ expression was significantly downregulated in only the head kidney in the B5 group. In contrast, $R$. glutinosa root powder enhanced iNOS gene expression in the head kidney of C. carpio [2]. The mechanism by which BPF downregulated $i N O S$ or $N F-\kappa B$ expression is not yet known. However, inhibition of NO activity by water extracts of banana peels has been reported in the literature [42].

HSPs are conserved proteins induced by heat and several noxious stimuli, including thermal shock, heavy metals, viruses, oxygen free radicals, and pathological stress [43]. HSP70 has a number of functions, including maintenance of cellular homeostasis, and general protective effects on all living organisms after stress [44]. Liu et al. [9] reported an increase in HSP70 mRNA expression in Macrobrachium rosenbergii after dietary administration of anthraquinone extract for 6 or 8 weeks. However, HSP70 expression in the blood of grass carp was remarkably downregulated after administration of Ficus carica polysaccharide [11]. In this study, expression of HSP70 was significantly elevated in the head kidney of the B3 and B5 groups, but BPF had no significant effect on HSP70 expression in the hepatopancreas. Dietary emodin and high doses of vitamin $\mathrm{C}$ increased HSP70 mRNA expression in Wuchang bream under high temperature stress, which is consistent with the results of the present study [12]. However, further studies are necessary to elucidate the mechanism by which BPF affects HSP70 expression in L. rohita. 
IL-10 and TGF- $\beta$ are regulatory cytokines with multifunctional roles in the immune system. IL-10 limits the magnitude of immune responses to foreign pathogens [45]. In this study, $I L-10$ expression was downregulated in the examined tissues of $L$. rohita fed a B3 or B5 diet. We observed a counter relationship between the expressions of TNF- $\alpha$ and $I L-10$. These results correspond with those of previous studies [2, 8 , 14]. Swain et al. [46] examined the mechanism of IL-10 induction by blocking NF- $\kappa \mathrm{B}$ signalling with BAY11-7082 in kidney cell culture of Catla catla. Blocking of NF- $\kappa$ B suppressed IL10 induction by lipopolysaccharides, suggesting that IL-10 was induced through the NF- $\kappa \mathrm{B}$ signalling pathway in Catla catla. Normally, TGF- $\beta$ inhibits B-and T-cell propagation and differentiation, antagonises proinflammatory cytokines ( $I L$ $1 \beta, T N F-\alpha$, and $I F N-\gamma$ ), and blocks expressions of $I L-1 \beta$ and $I L-12$ receptors [36]. In the present study, TGF- $\beta$ expression was significantly downregulated in the head kidney of the B5 groups alone, which is consistent with the results of previous studies $[2,8]$. Active constituents of banana peels may be responsible for observed anti-inflammatory properties. For example, vitamin $\mathrm{E}$, which is present in banana peel, is known to have potent anti-inflammatory activities [47]. Pectin is an eco-friendly and biodegradable polysaccharide present in banana peel and it has been used as an antimicrobial and anti-inflammatory agent [48]. Anti-inflammatory activities of banana peel extracts have also been reported in previous studies $[42,49]$.

After challenging with A. hydrophila, all BPF-fed groups exhibited higher survival than the control, and the highest survival (70\%) was observed in the B5 group. Our results indicated that BPF assisted in the control of microbial pathogens as well as infections. Higher survival in B5 fed group may be due to the augmentation of immune parameters (LA, PA, ACP, SOD, and CAT), decreased level of MDA, and stimulation of immune-related genes. Recently, several studies have shown that fish fed with herbal diets exhibited higher resistance to pathogen infections [2, 8, $10,13,14,33]$. Active components present in banana peel have higher antibacterial activities against gram-positive and gram-negative pathogens $[48,49]$. Moreover, hydroxyapatite nanoparticles derived from banana peel pectin had strong antibacterial activity against $S$. aureus and Escherichia coli [48].

\section{Conclusions}

Present study reveals that dietary administration of 5\% BPF (B5) for 60 days has the potential to modulate growth parameters, antioxidant status, immune responses, and expression of cytokine genes in L. rohita. In addition, 5\% BPF upregulated HSP70 expression and enhanced the postchallenge survival rate of $L$. rohita. Therefore, banana peel can be used as a feed additive in aquaculture to improve fish growth and disease resistance. Therefore, this inexpensive and easily available natural immunostimulant may represent a viable alternative to prophylactic use of chemicals in freshwater aquaculture. However, further studies should be conducted to better understand the mechanisms underlying dietary BPF in fish.

\section{Additional Points}

Venkatachalam Sukumaran present address is Department of Zoology, Kundavai Nachiyar Government Arts College for Women (Autonomous), Thanjavur, Tamil Nadu 613007, India.

\section{Competing Interests}

The authors declare no conflict of interests.

\section{Acknowledgments}

Authors gratefully acknowledge the research grant received from National Research Foundation of Korea, Ministry of Education (NRF-2014R1A2A1A11050093).

\section{References}

[1] FAO, The State of World Fisheries and Aquaculture, FAO, Rome, Italy, 2012.

[2] J.-L. Wang, X.-L. Meng, R.-H. Lu et al., "Effects of Rehmannia glutinosa on growth performance, immunological parameters and disease resistance to Aeromonas hydrophila in common carp (Cyprinus carpio L.)," Aquaculture, vol. 435, pp. 293-300, 2015.

[3] B. Maiti, M. Shetty, M. Shekar, I. Karunasagar, and I. Karunasagar, "Evaluation of two outer membrane proteins, Ahal and OmpW of Aeromonas hydrophila as vaccine candidate for common carp," Veterinary Immunology and Immunopathology, vol. 149, no. 3-4, pp. 298-301, 2012.

[4] B. Austin and D. A. Austin, Bacterial Fish Pathogens: Diseases of Farmed and Wild Fish, Springer-Praxis, Chichester, UK, 4th edition, 2007.

[5] S. Kumar, R. P. Raman, P. K. Pandey, S. Mohanty, A. Kumar, and K. Kumar, "Effect of orally administered azadirachtin on non-specific immune parameters of goldfish Carassius auratus (Linn. 1758) and resistance against Aeromonas hydrophila," Fish and Shellfish Immunology, vol. 34, no. 2, pp. 564-573, 2013.

[6] C. Uribe, H. Folch, R. Enriquez, and G. Moran, "Innate and adaptive immunity in teleost fish: a review," Veterinarni Medicina, vol. 56, no. 10, pp. 486-503, 2011.

[7] M. Reverter, N. Bontemps, D. Lecchini, B. Banaigs, and P. Sasal, "Use of plant extracts in fish aquaculture as an alternative to chemotherapy: current status and future perspectives," Aquaculture, vol. 433, pp. 50-61, 2014.

[8] S. S. Giri, S. S. Sen, C. Chi et al., "Effect of guava leaves on the growth performance and cytokine gene expression of Labeo rohita and its susceptibility to Aeromonas hydrophila infection," Fish and Shellfish Immunology, vol. 46, no. 2, pp. 217-224, 2015.

[9] B. Liu, X. Ge, Y. He et al., "Effects of anthraquinones extracted from Rheum officinale Bail on the growth, non-specific immune response of Macrobrachium rosenbergii," Aquaculture, vol. 310, no. 1-2, pp. 13-19, 2010.

[10] A. Sharma, A. D. Deo, S. T. Riteshkumar, T. I. Chanu, and A. Das, "Effect of Withania somnifera (L. Dunal) root as a feed additive on immunological parameters and disease resistance to Aeromonas hydrophila in Labeo rohita (Hamilton) fingerlings," Fish and Shellfish Immunology, vol. 29, no. 3, pp. 508-512, 2010. 
[11] X. Yang, J. L. Guo, J. Y. Ye, Y. X. Zhang, and W. Wang, “The effects of Ficus carica polysaccharide on immune response and expression of some immune-related genes in grass carp, Ctenopharyngodon idella," Fish and Shellfish Immunology, vol. 42, no. 1, pp. 132-137, 2015.

[12] J. H. Ming, J. Xie, P. Xu, X. P. Ge, W. B. Liu, and J. Y. Ye, "Effects of emodin and vitamin $\mathrm{C}$ on growth performance, biochemical parameters and two HSP70s mRNA expression of Wuchang bream (Megalobrama amblycephala Yih) under high temperature stress," Fish and Shellfish Immunology, vol. 32, no. 5, pp. 651-661, 2012.

[13] S. S. Giri, S. Jai Suda, V. Sukumaran, and S. C. Park, "Dietary emodin affects the growth performance, immune responses, and disease resistance of Labeo rohita against Aeromonas hydrophila," Aquaculture International, vol. 24, no. 1, pp. 85-99, 2016.

[14] R. Chakrabarti, P. K. Srivastava, N. Verma, and J. G. Sharma, "Effect of seeds of Achyranthes aspera on the immune responses and expression of some immune-related genes in carp Catla catla," Fish and Shellfish Immunology, vol. 41, no. 1, pp. 64-69, 2014.

[15] C. Svanborg, G. Godaly, and M. Hedlund, "Cytokine responses during mucosal infections: role in disease pathogenesis and host defence," Current Opinion in Microbiology, vol. 2, no. 1, pp. 99105, 1999.

[16] A. D'Hont, F. Denoeud, J.-M. Aury et al., “The banana (Musa acuminata) genome and the evolution of monocotyledonous plants," Nature, vol. 488, no. 7410, pp. 213-217, 2012.

[17] FAO, FAOSTAT, Food and Agriculture Organization, Geneva, Switzerland, 2013.

[18] T. H. Emaga, S. N. Ronkart, C. Robert, B. Wathelet, and M. Paquot, "Characterisation of pectins extracted from banana peels (Musa AAA) under different conditions using an experimental design," Food Chemistry, vol. 108, no. 2, pp. 463-471, 2008.

[19] T. H. Emaga, R. H. Andrianaivo, B. Wathelet, J. T. Tchango, and M. Paquot, "Effects of the stage of maturation and varieties on the chemical composition of banana and plantain peels," Food Chemistry, vol. 103, no. 2, pp. 590-600, 2007.

[20] J. L. Kelsey, "A review of research on effect of fibre intake on man," American Journal of Clinical Nutrition, vol. 31, pp. 142159, 1978.

[21] A. Pereira and M. Maraschin, "Banana (Musa spp) from peel to pulp: ethnopharmacology, source of bioactive compounds and its relevance for human health," Journal of Ethnopharmacology, vol. 160, pp. 149-163, 2015.

[22] L. P. G. Rebello, A. M. Ramos, P. B. Pertuzatti, M. T. Barcia, N. Castillo-Muñoz, and I. Hermosín-Gutiérrez, "Flour of banana (Musa AAA) peel as a source of antioxidant phenolic compounds," Food Research International, vol. 55, pp. 397-403, 2014.

[23] S. Sundaram, S. Anjum, P. Dwivedi, and G. K. Rai, "Antioxidant activity and protective effect of banana peel against oxidative hemolysis of human erythrocyte at different stages of ripening," Applied Biochemistry and Biotechnology, vol. 164, no. 7, pp. 11921206, 2011.

[24] W. Rattanavichai and W. Cheng, "Dietary supplement of banana (Musa acuminata) peels hot-water extract to enhance the growth, anti-hypothermal stress, immunity and disease resistance of the giant freshwater prawn, Macrobrachium rosenbergii," Fish and Shellfish Immunology, vol. 43, no. 2, pp. 415426, 2015.
[25] S. S. Giri, S. S. Sen, and V. Sukumaran, "Role of HSP70 in cytoplasm protection against thermal stress in rohu, Labeo rohita," Fish and Shellfish Immunology, vol. 41, no. 2, pp. 294-299, 2014.

[26] K. J. Livak and T. D. Schmittgen, "Analysis of relative gene expression data using realtime quantitative PCR and the $2^{-\triangle \Delta C T}$ method," Methods, vol. 25, pp. 402-408, 2001.

[27] M. Soltani, R. Alimardani, and M. Omid, "Prediction of banana quality during ripening stage using capacitance sensing system," Australian Journal of Crop Science, vol. 4, no. 6, pp. 443-447, 2010.

[28] AOAC, Official Methods of Analyses, Association of Official Analytical Chemists, Washington, DC, USA, 16th edition, 1997.

[29] APHA, AWWA, and WEF, Standard Methods for the Examination of Water and Waste Water, American Public Health Association, American Water Works Association, Water Environment Association, Washington, DC, USA, 20th edition, 1998.

[30] A. E. Ellis, "Lysozyme assay," in Techniques in Fish Immunology, J. S. Stolen, T. C. Fletcher, D. P. Anderson, B. S. Robertson, and W. B. Van Muiswinkel, Eds., pp. 101-103, SOS Publications, Fair Haven, NJ, USA, 1990.

[31] T. Yano, "Assays of hemolytic complement activity," in Techniques in Fish Immunology, J. S. Stolen, T. C. Fletcher, D. P. Anderson, S. L. Kaattari, and A. E. Rowley, Eds., pp. 131-141, SOS Publications, Fair Haven, NJ, USA, 1992.

[32] W.-Q. Cai, S.-F. Li, and J.-Y. Ma, "Diseases resistance of Nile tilapia (Oreochromis niloticus), blue tilapia (Oreochromis aureus) and their hybrid (female Nile tilapia $\times$ male blue tilapia) to Aeromonas sobria," Aquaculture, vol. 229, no. 1-4, pp. 79-87, 2004.

[33] C.-N. Zhang, X.-F. Li, W.-N. Xu et al., "Combined effects of dietary fructooligosaccharide and Bacillus licheniformis on innate immunity, antioxidant capability and disease resistance of triangular bream (Megalobrama terminalis)," Fish and Shellfish Immunology, vol. 35, no. 5, pp. 1380-1386, 2013.

[34] H. H. Draper, E. J. Squires, H. Mahmoodi, J. Wu, S. Agarwal, and M. Hadley, "A comparative evaluation of thiobarbituric acid methods for the determination of malondialdehyde in biological materials," Free Radical Biology and Medicine, vol. 15, no. 4, pp. 353-363, 1993.

[35] M. Á. Esteban, "An overview of the immunological defenses in fish skin," ISRN Immunology, vol. 2012, Article ID 853470, 29 pages, 2012.

[36] L. Weifen, Z. Xiaoping, S. Wenhui et al., "Effects of Bacillus preparations on immunity and antioxidant activities in grass carp (Ctenopharyngodon idellus)," Fish Physiology and Biochemistry, vol. 38, no. 6, pp. 1585-1592, 2012.

[37] B. A. Freeman and J. D. Crapo, "Biology of disease: free radicals and tissue injury," Laboratory Investigation, vol. 47, no. 5, pp. 412-426, 1982.

[38] B. Magnadóttir, "Innate immunity of fish (Overview)," Fish and Shellfish Immunology, vol. 20, no. 2, pp. 137-151, 2006.

[39] I. Fridovich, "Superoxide radical and superoxide dismutases," Annual Review of Biochemistry, vol. 64, pp. 97-112, 1995.

[40] C. J. Secombes, T. Wang, S. Hong et al., "Cytokines and innate immunity of fish," Developmental and Comparative Immunology, vol. 25, no. 8-9, pp. 713-723, 2001.

[41] B. Gorgoglione, T. Wang, C. J. Secombes, and J. W. Holland, "Immune gene expression profiling of Proliferative Kidney Disease in rainbow trout Oncorhynchus mykiss reveals a dominance of anti-inflammatory, antibody and T helper cell-like activities," Veterinary Research, vol. 44, no. 1, article 55, 2013. 
[42] P. Phuaklee, S. Ruangnoo, and A. Itharat, "Anti-inflammatory and antioxidant activities of extracts from Musa sapientum peel," Journal of the Medical Association of Thailand, vol. 95, pp. 142-146, 2012.

[43] E. D. I. Vega, M. R. Hall, B. M. Degnan, and K. J. Wilson, "Shortterm hyperthermic treatment of Penaeus monodon increases expression of heat shock protein 70 (HSP70) and reduces replication of gill associated virus (GAV)," Aquaculture, vol. 253, no. 1-4, pp. 82-90, 2006.

[44] N. Basu, A. E. Todgham, P. A. Ackerman et al., "Heat shock protein genes and their functional significance in fish," Gene, vol. 295, no. 2, pp. 173-183, 2002.

[45] M. O. Li and R. A. Flavell, "Contextual regulation of inflammation: a duet by transforming growth factor- $\beta$ and interleukin10," Immunity, vol. 28, no. 4, pp. 468-476, 2008.

[46] B. Swain, M. Samanta, M. Basu et al., "Molecular characterization, inductive expression and mechanism of interleukin-10 gene induction in the Indian major carp, catla (Catla catla)," Aquaculture Research, vol. 43, no. 6, pp. 897-907, 2012.

[47] A. Scalbert, I. T. Johnson, and M. Saltmarsh, "Polyphenols: antioxidants and beyond," The American Journal of Clinical Nutrition, vol. 81, no. 1, pp. 215-217, 2005.

[48] D. Gopi, K. Kanimozhi, N. Bhuvaneshwari, J. Indira, and L. Kavitha, "Novel banana peel pectin mediated green route for the synthesis of hydroxyapatite nanoparticles and their spectral characterization," Spectrochimica Acta Part A: Molecular and Biomolecular Spectroscopy, vol. 118, pp. 589-597, 2014.

[49] P. Jain, M. H. Bhuiyan, K. R. Hossain, and S. C. Bachar, "Antibacterial and antioxidant activities of local seeded banana fruits," African Journal of Pharmacy and Pharmacology, vol. 5, no. 11, pp. 1398-1403, 2011. 


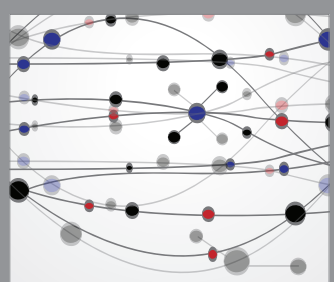

The Scientific World Journal
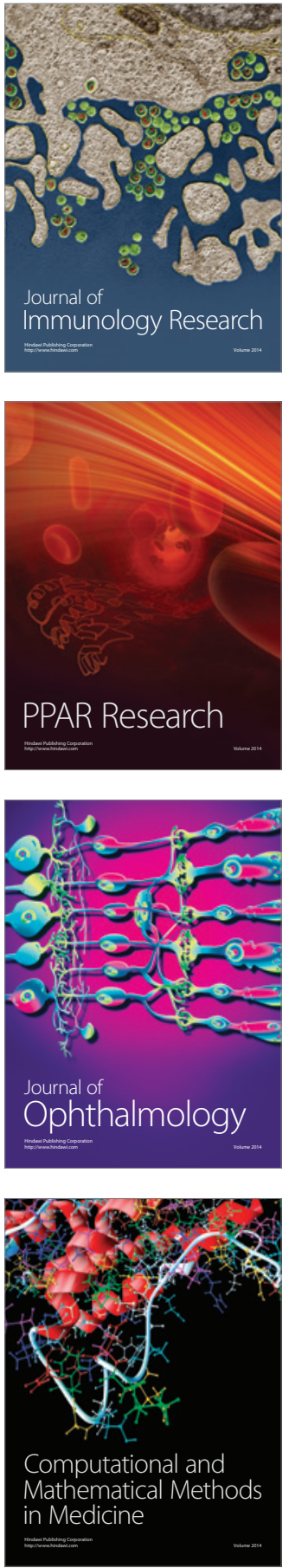

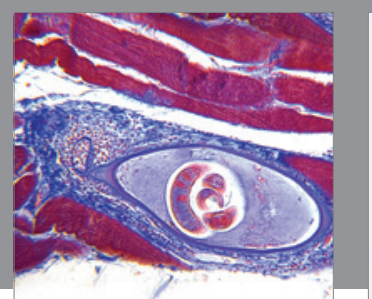

Gastroenterology Research and Practice

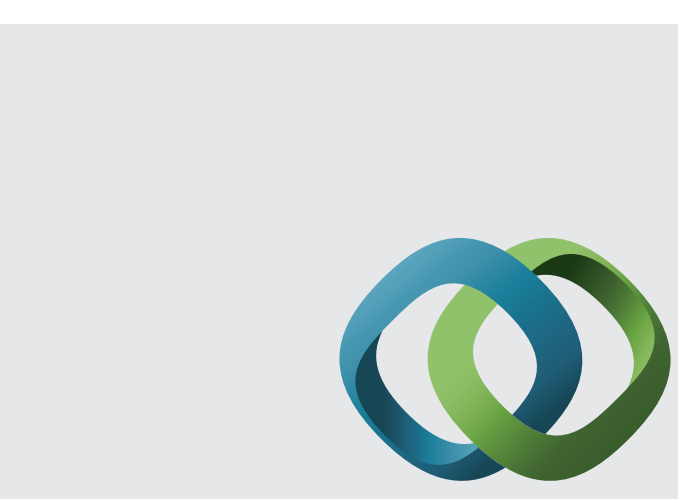

\section{Hindawi}

Submit your manuscripts at

http://www.hindawi.com
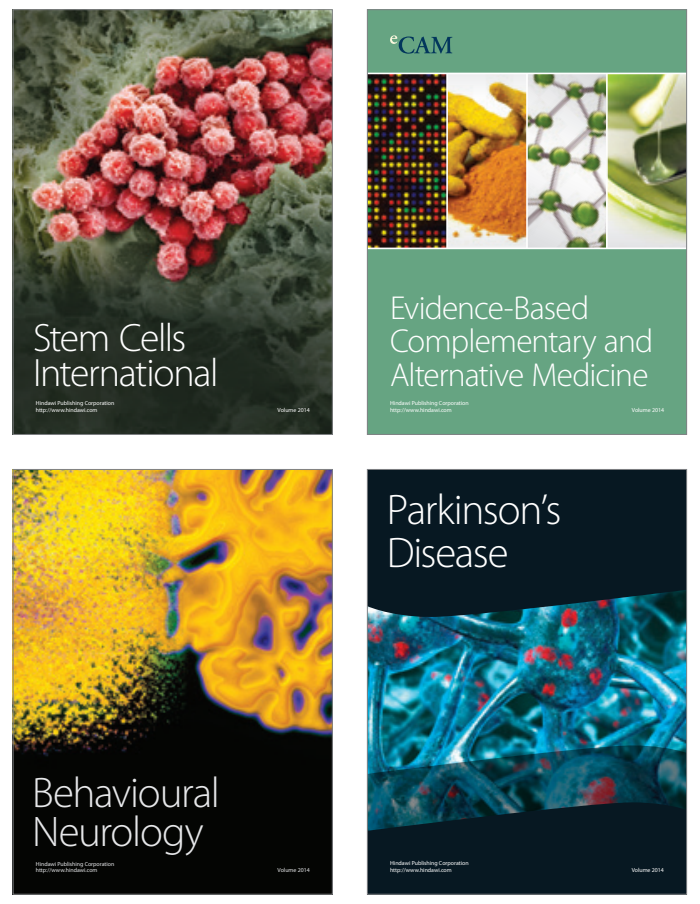
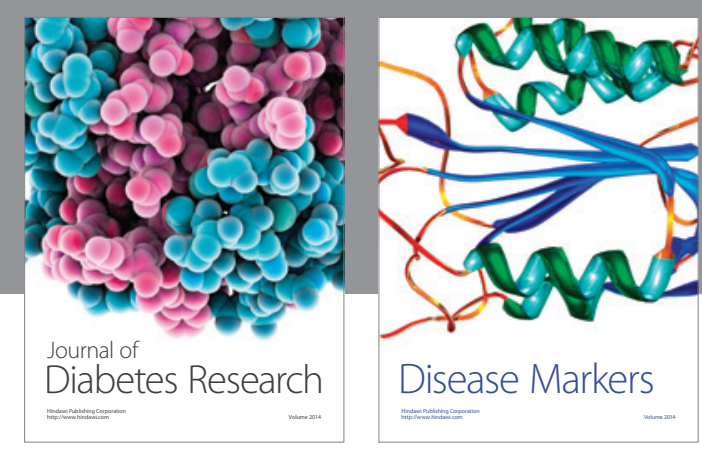

Disease Markers
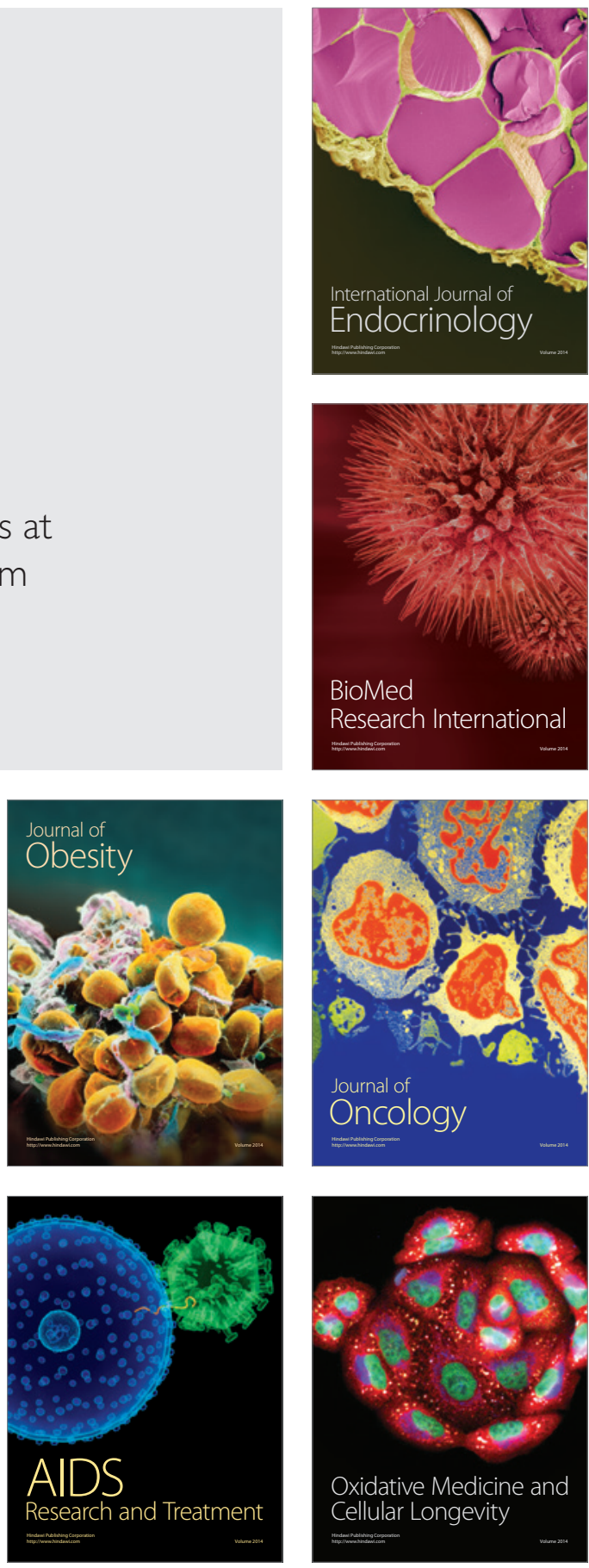